Endocrinol. Japon. 1966, 13 (1), 1 6

\title{
A CASE OF PSEUDOHYPOPARATHYROIDISM PRESENTING AS EPILEPSY WITH INCREASED PARATHYROID HORMONE-LIKE ACTIVITY IN URINE
}

\author{
Hironori NAKAJIMA, YasuHIKo FUKUMOTO \\ AND MASUmitsu NAKATA
}

Department of Pediatrics, Chiba University School of Medicine, Chiba, Japan

Takuo FUjita and Hajime ORimo

Department of Geriatrics, University of Tokyo Faculty of Medicine, Tokyo, Japan

Secondary hyperparathyroidism in pseudohypoparathyroidism was suggested by Kolb (1962) based mainly on bone X-ray findings characteristic to parathyroid hyperfunction such as subperiosteal resorption and osteitis fibrosa. We have recently experienced a case of typical pseudohypoparathyroidism in which the parathyroid hormone-like calcium-mobilizing activity in urine was increased, although bone changes failed to show characteristic changes of parathyroid hormone excess.

\section{CASE REPORT}

A 13 years 8 months old boy visited the Outpatient Clinic of the Department of Pediatrics, Chiba University Hospital in June 1962 with the chief complaint of convulsive seizure. Family history was free of hereditary disease or consanguinous marriage. Past history was negtive except for pneumonia at the age of 6 months.

The present illness started in April 1962 when patient began to complain of headache. An attack of loss of consciousness with clonic convulsions lasting approximately 5 mins., first experienced in May, repeated itself with intervals of about 10 days. Tonic and clonic convulsions on the left side of the body then appeared 15 to 16 times a day for 5 consecutive days in the middle of June. Anticonvulsant therapy temporarily relieved the seizure, which recurred following acute tonsillitis towards the end of June.

Physical examination revealed a short, fat boy with the body length of $132.1 \mathrm{~cm}(-2.15 \sigma$, corresponding to 10 years and 7 months of age), and the body weight of $31.5 \mathrm{~kg}(-1.18 \sigma)$ (Fig. 1). Head and body hairs were not unusual and no abnormal pigmentation was noted. Irregular subcutaneous nodules, subsequently demonstrated to be calcifications, were noted in the popliteal regions on both sides (Fig. 2). Neck, chest and abdomen were esssentially negative. Neurological examination was negative except for a slight hyporeflexia on the right half of the body and positive Chadock reflex on the right side. Chvostek and Trousseau phenomena were absent.

Laboratory findings revealed; slight anemia, leucocytosis which later disappeared as the tonsillitis subsided, total protein $7.5 \mathrm{~g} / 100 \mathrm{ml}, \mathrm{A} / \mathrm{G}$ ratio $1.38, \mathrm{Na} 142.0 \mathrm{mEq} / \mathrm{L}, \mathrm{Cl} 98.2 \mathrm{mEq} / \mathrm{L}, \mathrm{K} 4.8 \mathrm{mEq} / \mathrm{L}$, $\mathrm{Ca} 7.2 \mathrm{mg} / 100 \mathrm{ml}$, inorganic phosphorus $6.5 \mathrm{mg} / 100 \mathrm{ml}$, alkaline phosphatase 4.6 Bessey-Lowry

Received for publication August 9, 1965. 


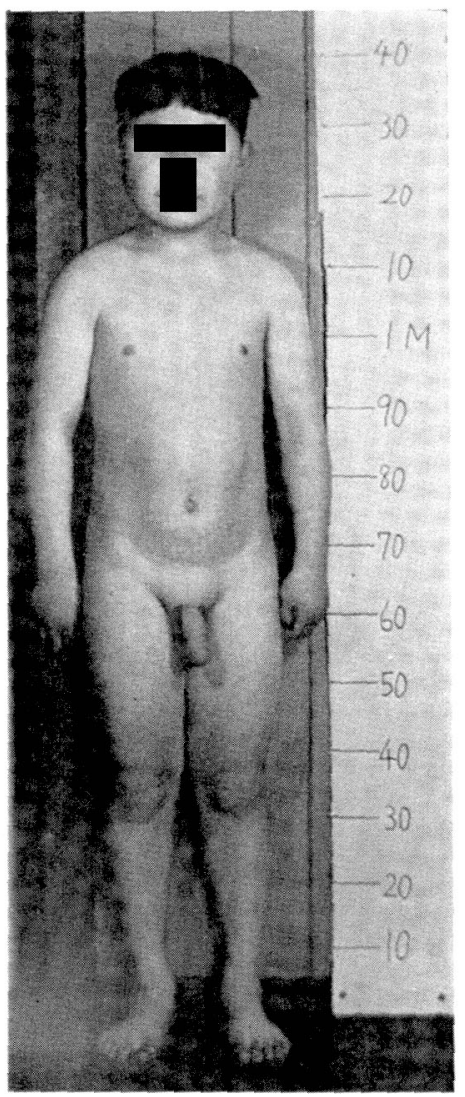

Fig. 1. Appearance of patient, showing characteristic somatotype of pseudohypoparathyroidism such as short stature, fat body and round face

units, negative urine and feces, PSP excretion $40 \%$ in 15 mins. and $70 \%$ in 2 hrs., negative cerebrospinal fluid, PBI $5.3 \mu \mathrm{g} / 100 \mathrm{ml}$, thyroidal ${ }^{13^{4}}$ I-uptake $23.4 \%$ per $24 \mathrm{hrs}$., red cell uptake of ${ }^{131}$ I-triiodothyronine $16.9 \%$, uninary 17 -OHCS $2.7 \mathrm{mg} / 24 \mathrm{hrs}$, QRS interval of $0.43 \mathrm{sec}$. on ECG, negative bone and skull X-ray and irregular alpha-waves of 8 to $9 \mathrm{c} / \mathrm{s}$ interspersed with sharp and wave complex in the occipital region and continuous wave in the frontal area with positive build up upon hyperventilation in the EEG, suggesting symptomatic epilepsy. "Parathyroid Injection" (Eli Lilly), 50 units per $\mathrm{m}^{2}$ body surface injected intravenously, failed to cause a significant phosphaturia whereas the same preparation caused a 3 to 4 folds increase in urinary phosphorus excretion in normal children (Table 1). Intravenous infusion of $15 \mathrm{mg} / \mathrm{kg}$ calcium in the form of gluconate dissolved in $400 \mathrm{~m} l$ physiological saline over a period of $4 \mathrm{hrs}$. caused a $16 \%$ drop of urinary phosphorus excretion in the next $24 \mathrm{hrs}$., while serum phosphorus was raised $3.1 \mathrm{mg} / 100 \mathrm{ml} 4 \mathrm{hrs}$. after the end of the infusion (Table 2). Intelligence quotient was 86 according to Tanaka-Binet's method.

Parathyroid hormone-like activity in urine was assayed after extracting the urine with benzoic acid adsorption (Fujita et al., 1961) followed by purification with XE-64 ion-exchange resin and assayed by ${ }^{32} \mathrm{P}$ excretion in parathyroidectomized rats (Fujita et al., 1961) and elevation of serum 


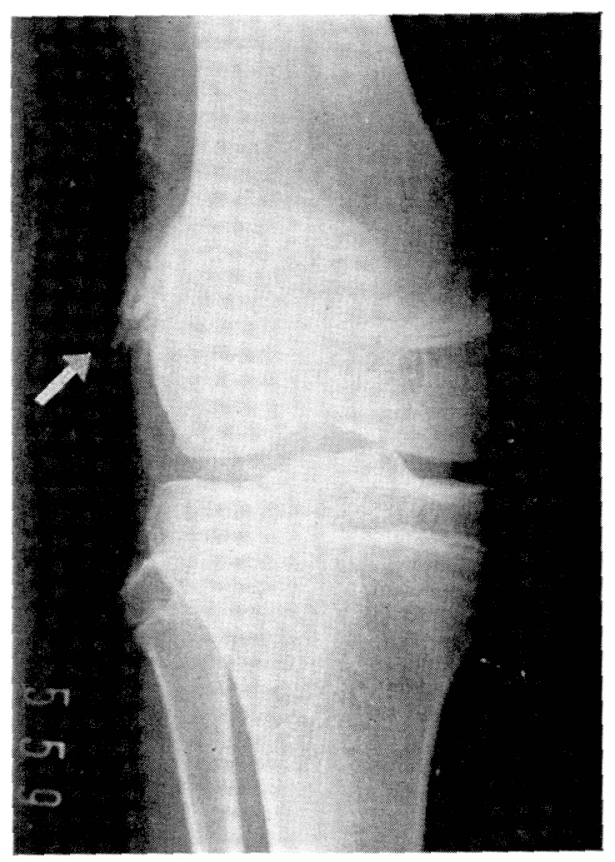

Fig. 2. Roentgenogram of right knee, showing subcutaneous calcification in the popliteal region (arrow)

Table 1. Results of Ellsworth-Howard test

\begin{tabular}{|c|c|c|c|c|c|}
\hline Time & $\begin{array}{c}\text { Serum } \\
\text { phosphorus } \\
(\mathrm{mg} / 100 \mathrm{ml})\end{array}$ & $\begin{array}{l}\text { Urinary } \\
\text { volume } \\
(\mathrm{ml} / 24 \mathrm{hr} .)\end{array}$ & $\begin{array}{l}\text { Urinary } \\
\text { phosphorus } \\
(\mathrm{mg} / 100 \mathrm{ml})\end{array}$ & $\begin{array}{l}\text { Urinary excretion } \\
\text { of phosphorus } \\
(\mathrm{mg} / \mathrm{hr} .)\end{array}$ & $\begin{array}{l}\text { Phosphorus } \\
\text { clearance } \\
\text { (ml/min.) }\end{array}$ \\
\hline $7: 30 \sim 9: 30$ a.m. & 5.7 & 200 & 13.0 & 26.0 & 6.7 \\
\hline $8: 30 \sim 9: 30$ a.m. & 5.6 & 330 & 11.0 & 33.0 & 8.7 \\
\hline \multicolumn{6}{|c|}{ Parathormone 56 unifs (50 units $/ \mathrm{m}^{2}$ ), intravenously } \\
\hline $9: 30 \sim 10: 30$ a.m. & 5.8 & 90 & 31.0 & 27.9 & 7.2 \\
\hline $10: 30 \sim 11: 30$ a.m. & 10.2 & 310 & 15.0 & 46.5 & 6.7 \\
\hline $\begin{aligned} 11: 30 \text { a.m. } & \\
& \sim 12: 30 \text { p.m. }\end{aligned}$ & 9.8 & 85 & 24.0 & 20.4 & 4.7 \\
\hline
\end{tabular}

calcium in low calcium-fed parathyroidectomized rats (Munson, 1961). Parathyroid hormonelike calcium-mobilizing activity was $56 \mathrm{USP}$ units $/ 24 \mathrm{hr}$. during AT-10 administration and 118 and 64 units 7 and 10 days after discontinuation respectively, while corresponding values averaged 15 units in 6 normal subjects. Parathyroid homone-like phosphaturic activity, on the other hand, stayed within normal limits of 30 units $/ 24 \mathrm{hr}$; 26 units $/ 24 \mathrm{hr}$. during AT-10 administration and 22 and 10 units 7 days and 10 days after discontinuation respectively (Table 3 ).

Treatment with $3 \mathrm{~g}$ of calcium lactate and 30,000 units of vitamin $\mathrm{D}_{2}$ per day failed to restore serum calcium to normal and the convulsions kept to occur with intervals of about 10 
days. Administration of $2 \mathrm{ml}$ per day of AT-10, started in November, completely abolished the convulsions and restored the serum calcium and phosphorus to normal (Fig. 3). Continuation of AT-10 medication last two and half years successfully controled the clinical picture and patient grew $11 \mathrm{~cm}$ during the 1 year 10 month period.

Table 2. Results of intravenous calcium test (Howard 1953)

\begin{tabular}{lccccc}
\hline & $\begin{array}{c}\text { Serum } \\
\text { calcium } \\
(\mathrm{mg} / 100 \mathrm{ml})\end{array}$ & $\begin{array}{c}\text { Serum } \\
\text { phosphorus } \\
(\mathrm{mg} / 100 \mathrm{ml})\end{array}$ & $\begin{array}{c}\text { Urinary } \\
\text { volume } \\
(\mathrm{m} / / 24 \mathrm{hr} .)\end{array}$ & $\begin{array}{c}\text { Urinary } \\
\text { phosphorus } \\
(\mathrm{mg} / 100 \mathrm{ml})\end{array}$ & $\begin{array}{c}\text { Urinary excretion } \\
\text { of phosphorus } \\
(\mathrm{mg} / 24 \mathrm{hr} .)\end{array}$ \\
\hline Control day & 7.2 & 4.6 & 1600 & 0.82 & 1312 \\
\hline $\begin{array}{l}\text { Test day } \\
\text { Hours after start of } \\
\text { calcium infusion* }\end{array}$ & & & 1900 & 0.58 & 1102 \\
$2 \mathrm{hr}$. & 8.4 & 4.7 & & & \\
$8 \mathrm{hr}$. & 7.6 & 7.8 & & & \\
$24 \mathrm{hr}$. & 8.2 & 5.1 & & & \\
\hline
\end{tabular}

* $400 \mathrm{ml}$ physiologic saline containing $15 \mathrm{mg} / \mathrm{kg}$ calcium in the form of gluconate was administered for a $4 \mathrm{hr}$. period.

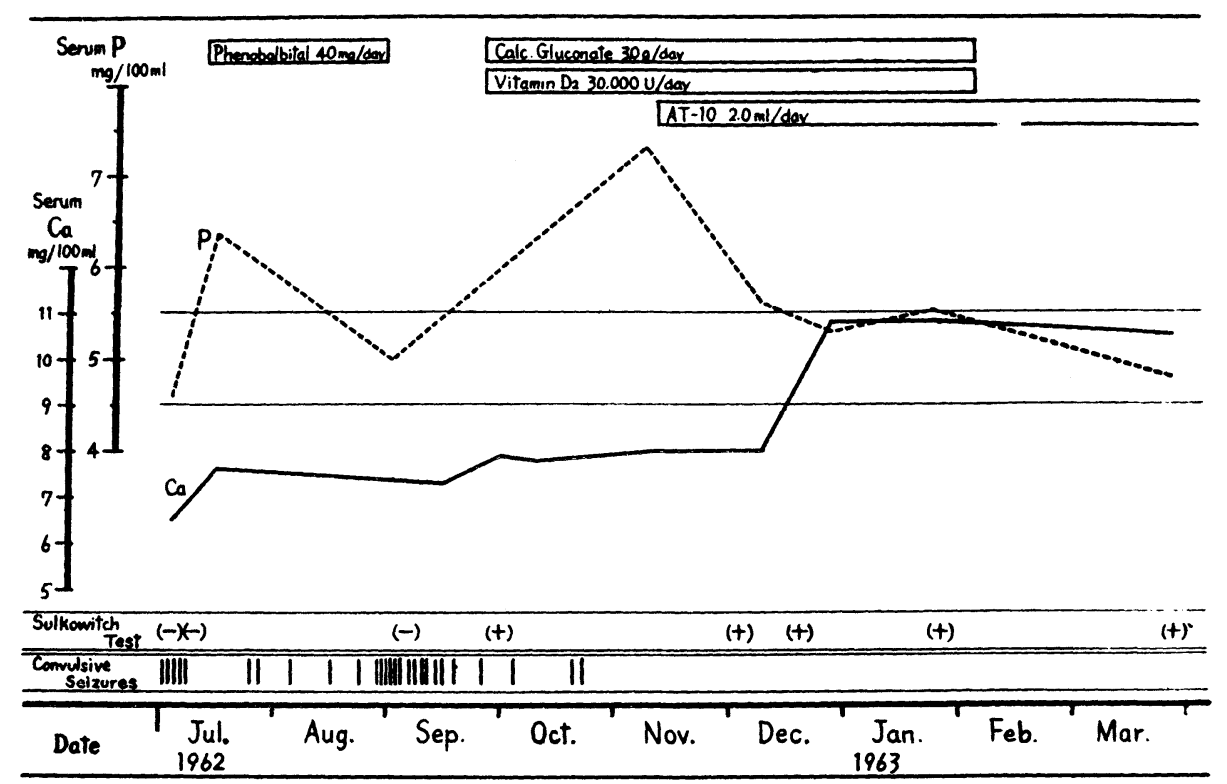

Fig. 3. Changes of serum calcium and inorganic phosphorus during treatment.

Administration of $2 \mathrm{ml}$ per day of AT-10, started in November, completely abolished the convulsions and restored the serum calcium and phosphorus to normal after about 6 weeks. 
Table 3. Results of bioassays of parathyroid hormone-like activity in urine

\begin{tabular}{lcccc}
\hline & Normal & February, 1963. & March, 1963 \\
\hline value & $\begin{array}{c}\text { During AT-10 } \\
\text { administration }\end{array}$ & $\begin{array}{c}7 \text { days after } \\
\text { discontinuation } \\
\text { of AT-10 }\end{array}$ & $\begin{array}{c}10 \text { days after } \\
\text { discontinuation } \\
\text { of AT-10 }\end{array}$ \\
\hline $\begin{array}{c}\text { USP. U } \\
\text { Calcium-mobilizing } \\
\text { activity }\end{array}$ & $0-30$ & USP. U & USP. U & 118 \\
$\begin{array}{c}\text { Phosphaturic } \\
\text { activity }\end{array}$ & 56 & 26 & 22 & USP. U \\
\hline
\end{tabular}

* Average in 6 normal subject

\section{DISCUSSION}

The diagnosis of pseudohypoparathyroidism in this case was based upon the increased neuromuscular excitability resulting in convulsive seizures, round face and short stature, subcutaneous calcification, low intelligence, hypocalcemia, hyperphosphatemia negative response to exogenous parathyroid extract, and normal response to calcium infusion. Although the physiological significance of urinary parathyroid hormone-like activity has not been established as yet due to the inherent difficulty in the method of extraction and bioassay, the increase in calciummobilizing activity at least suggests the presence of some parathyroid hormone-like activity in the organism in contradistinction from idiopathic hypoparathyroidism.

In view of the absence of detectable amount of parathyroid hormone-like calcium-mobilizing activity in half of the normal subjects studied, parathyroid hyperfunction in pseudohypoparathyroidism as suggested by Kolb (1962) remains an interesting possibility. Costello (1963) has presented a 6 year old girl with biochemical hypoparathyroidism and X-ray picture of hyperparathyroidism but without the physical characterisitics of pseudohypoparathyroidism, suggesting a new syndrome of hypo-hyperparathyroidism. The present case apparently does not belong to this category in view of the almost complete clinical picture of pseudohypoparathyroidism. Bioassay of parathyroid hormone-like activity in urine might be of value in distinguishing between idiopathic hypoparathyroidism and pseudohypoparthyroidism.

\section{SUMMARY}

A 13 years old male complained of headache and convulsive seizures and short spells of loss of consciousness for last 2 months. Typical clinical features for pseudohypoparathyroidism such as short stature, round face, subcutaneous calcification, and lack of phosphaturic response to parathyroid extract, hypocalcemia and hyperphosphatemia, were noted. Benzoic acid extract of the urine revealed an increased parathyroid hormone-like calcium-mobilizing activity, which decreased after treatment with AT-10, and a normal phosphaturic activity. Parathyroid 
hyperfunction due to the target organ failure may be suggested although no other evidence of secondary hyperparathyroidism was demonstrated.

\section{AGKNOWLEDGMENTS}

We wish to express our thanks to Prof. S. Kubo and Prof. M. Yoshikawa for their helpful suggestions.

\section{REFERENCES}

Costello, J.M. and C.E. Dent (1963). Arch. Dis. Childh. 38, 397.

Davies, B.M.A. (1958). J. Endocrinol. 16, 369.

Fujita, T., H. Morii, H. Ibayashi, Y. Takahashi and S. Okinaka (1961). Acta Endocrinol. 38, 321.

Kolb, F.O. and H.L. Stienbach (1962). J. Clin. Endocrinol. and Metab. 22, 59.

Munson P.L., O.A. Iseri, A.D. Kenny, V.H. Cohen and M.C. Sheps (1955). J. Dent. Res. 34, 714 .

Munson, P.L. (1961). The parathyroid, p. 94. Charles C. Thomas, Springfield. 